\title{
The Medicago truncatula N5 Gene Encoding a Root-Specific Lipid Transfer Protein Is Required for the Symbiotic Interaction with Sinorhizobium meliloti
}

\author{
Youry Pii, ${ }^{1}$ Alessandra Astegno, ${ }^{2}$ Elisa Peroni, ${ }^{2}$ Massimo Zaccardelli, ${ }^{3}$ Tiziana Pandolfini, ${ }^{1}$ and \\ Massimo Crimi ${ }^{1}$ \\ ${ }^{1}$ Dipartimento Scienze, Tecnologie e Mercati del Vino, University of Verona, San Floriano (VR); ${ }^{2}$ Dipartimento Scientifico \\ e Tecnologico, University of Verona, Verona, Italy; ${ }^{3}$ CRA-Centro di Ricerca per l'Orticoltura, Pontecagnano-Battipaglia (SA), \\ Italy
}

Submitted 18 May 2009. Accepted 27 July 2009.

\begin{abstract}
The Medicago truncatula N5 gene is induced in roots after Sinorhizobium meliloti infection and it codes for a putative lipid transfer protein (LTP), a family of plant small proteins capable of binding and transferring lipids between membranes in vitro. Various biological roles for plant LTP in vivo have been proposed, including defense against pathogens and modulation of plant development. The aim of this study was to shed light on the role of MtN5 in the symbiotic interaction between $M$. truncatula and $S$. meliloti. MtN5 cDNA was cloned and the mature MtN5 protein expressed in Escherichia coli. The lipid binding capacity and antimicrobial activity of the recombinant MtN5 protein were tested in vitro. MtN5 showed the capacity to bind lysophospholipids and to inhibit $M$. truncatula pathogens and symbiont growth in vitro. Furthermore, MtN5 was upregulated in roots after infection with either the fungal pathogen $F u s a-$ rium semitectum or the symbiont $S$. meliloti. Upon $S$. meliloti infection, MtN5 was induced starting from 1 day after inoculation (dpi). It reached the highest concentration at 3 dpi and it was localized in the mature nodules. MtN5silenced roots were impaired in nodulation, showing a $50 \%$ of reduction in the number of nodules compared with control roots. On the other hand, transgenic roots overexpressing MtN5 developed threefold more nodules with respect to control roots. Here, we demonstrate that MtN5 possesses biochemical features typical of LTP and that it is required for the successful symbiotic association between $M$. truncatula and S. meliloti.
\end{abstract}

Plant lipid transfer proteins (LTP) were isolated for the first time approximately 30 years ago and were characterized by their ability to facilitate the transfer of phospholipids between a donor and an acceptor membrane in vitro (Kader 1975). Plant LTP are small, soluble basic proteins with an isoelectric point (pI) ranging between 9 and 10 (Kader 1997). The primary sequence of LTP contains eight strictly conserved cysteine residues which are engaged in the formation of four intrachain disulfide bonds. The three-dimensional architecture of several LTP has been solved by nuclear magnetic resonance and X-ray

Corresponding author: Tiziana Pandolfini; Telephone: +39-45-8027918; Fax: +39-45-8027929; E-mail: tiziana.pandolfini@univr.it

* The $\boldsymbol{e}$-Xtra logo stands for "electronic extra" and indicates that two supplementary figures are published online. crystallography, and a structure of four $\alpha$-helices enclosing an internal hydrophobic cavity has been revealed (Lerche et al. 1997; Lee et al. 1998; Samuel et al. 2002; Pons et al. 2003; Hoh et al. 2005). Plant LTP are grouped into two main families (Boutrot et al. 2008). The first family, LTP1, comprises proteins which have a molecular mass of approximately $9 \mathrm{kDa}$. In addition to the eight perfectly conserved cysteine residues, type 1 LTP display other conserved characteristics, such as the presence of small hydrophobic amino acids throughout the whole sequence which participate in the definition of the binding tunnel hydrophobicity (Yeats and Rose 2008). This cavity runs through the molecule's axes and accommodates fatty acids or lysophospholipids (de Oliveira Carvalho and Moreira Gomes 2007).

The second family, LTP2, comprises proteins with an average molecular mass of $7 \mathrm{kDa}$. Compared with the LTP1 family, there are considerably fewer studies concerning the architectture of LTP belonging to family 2 (Samuel et al. 2002; Pons et al. 2003; Hoh et al. 2005). Site-directed mutagenesis studies have recently highlighted a crucial role for Leu8, Phe36, and Val49 in the maintenance of both structure and lipid-binding ability of rice LTP2 (Cheng et al. 2007). In other members of the LTP2 family, the last two amino acids can be replaced by residues with similar chemical characteristics (i.e., Leu and Ile, respectively).

All known plant LTP are synthesized as precursors with an $\mathrm{N}$-terminal signal peptide which targets the mature protein toward the secretory pathway. Therefore, a role in the intracellular lipid trafficking has been ruled out for plant LTP (Kader 1997). The biological function of plant LTP is still not fully elucidated. Some experimental evidence suggests the involvement of LTP in different aspects of plant biology.

Many LTP belonging to the LTP1 family have been proven to participate in defense responses against bacterial and fungal pathogens. Several LTP1s from different plants exhibit antimicrobial activity against both pathogenic bacteria and fungi in vitro (Terras et al. 1992; Molina et al. 1993; Segura et al. 1993; Cammue et al. 1995; Ge et al. 2003) and the overexpression of these proteins in transgenic plants conferred enhanced resistance against a wide range of plant pathogens (Mourgues et al. 1998; Iwai et al. 2002; Jung et al. 2005; Roy-Barman et al. 2006; Patkar and Chatoo 2006; Yang et al. 2008). The defensive role of LTP has also been corroborated by the observation that many isoforms are upregulated during infection in plants (García-Olmedo et al. 1995; Jung et al. 2003), and this feature has resulted in the inclusion of LTP in the pathogenesis-related 
(PR) protein family (Van Loon and Van Strien 1999). To our knowledge, there are no clear indications that LTP2s act as antimicrobial proteins.

LTP can participate in the defense reaction as components of the signaling pathway that lead to systemic acquired resistance (SAR). The evidence of this role was obtained with the dirl-1 mutant of Arabidopsis thaliana, which was impaired in the SAR induction but not in the local response (Maldonado et al. 2002). DIR1 displays some structural and lipid-binding properties similar to plant LTP2s, except for the acidic pI. However, on the basis of both structural and functional specific features, it was proposed as a new type of LTP (Lascombe et al. 2008).

Evidence for LTP1s acting as systemic resistance inducers originated from the observation that a Nicotiana tabacum LTP1 (NtLTP1) has the capability to bind jasmonic acid (JA) (Buhot et al. 2004). The complex NtLTP1-JA is able to interact with the elicitin receptor on the plasma membrane, providing long-distance protection against Phytophthora parasitica infection in tobacco plants (Buhot et al. 2004).

Recently, LTP have also been implicated in plant developmental processes such as the induction of cell-wall loosening and the synthesis of the cuticle (Nieuwland et al. 2005; Cameron et al. 2006). A putative involvement of LTP in the symbiotic relationship has been hypothesized, based on the data obtained from a number of transcriptome analyses aimed at monitoring changes in gene expression elicited by rhizobia infection.

The transcriptome analysis of Medicago truncatula root nodules has led to the discovery of a gene family named nodulespecific cysteine-rich (NCR), which is composed of 300 members. Some of these NCR, shown to be expressed in different phases of nodule development and localized in different zones of the emerging organ, belong to the LTP family. This suggests that these genes could be involved in the formation of root nodules (Mergaert et al. 2003).
MtN5 is a gene from M. truncatula, which was identified by means of a differential screening aimed at isolating new genes induced during the early phases of the symbiosis between $M$. truncatula and Sinorhizobium meliloti (Gamas et al. 1996). Thus, it was recognized as an early marker of the symbiosis and, on the basis of the sequence homology, it was annotated as a putative LTP (El Yahyaoui et al. 2004).

In this study, we have demonstrated that MtN5 is able to bind lysophospholipids, possesses a weak antimicrobial activity in vitro, and is induced in M. truncatula roots upon Fusarium spp. infection. Furthermore, we have shown that MtN5 protein is specifically expressed during the early phases of the symbiosis and accumulates in the mature nodules. Using an RNA-interference (RNAi) approach to suppress MtN5 function, we proved that $M t N 5$ is required for the successful establishment of the symbiotic association between $M$. truncatula and S. meliloti. Accordingly, the overexpression of the MtN5 gene promoted nodulation.

\section{RESULTS}

\section{MtN5 is an LTP2-like protein.}

The MtN5 gene encodes for a 643-nucleotide-long messenger $(\mathrm{m})$ RNA which produces a putative protein of 102 amino acids containing a 27 -amino-acid-long N-terminal signal peptide for the secretory pathway. Recently, it has been experimentally demonstrated that MtN5 protein is localized in the apoplastic space (Kusumawati et al. 2008). The deduced sequence of the mature MtN5 protein was compared with the sequences of proteins belonging to the two different LTP families (type 1 and type 2) (Fig. 1A and B). The multiple sequence alignment shows that the homology with representative members of the LTP1 family is restricted to the eight-cysteine motif and a few other residues ( $14.5 \%$ identity, $34.2 \%$ similarity)

A

\begin{tabular}{|c|c|}
\hline & . \\
\hline $\mathrm{v}$ & $--\mathrm{AVI}$ \\
\hline dulcis & AY-SAMTKLALLVVALCMVV-SVPIA-Q-AITCGQVSSN-LA \\
\hline domestica & 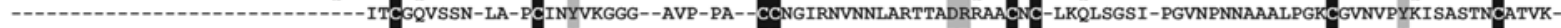 \\
\hline armenica & 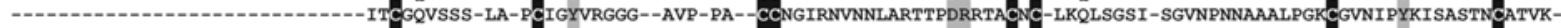 \\
\hline ica & LKNLAGSI-SGVNPNNAAG \\
\hline$m$ & LKSAAGAI-SGINLGKAAG \\
\hline tum & FVF-CMVV-VAP \\
\hline $\operatorname{tum}$ & -CMVV-GAPI \\
\hline$d a$ & -CMVF-SASY \\
\hline I.a & -CMYV-GAPY \\
\hline 3.n $n$ & LVGAANAFPT-LNAARAAGI \\
\hline ana & AG--VMKLACLLLA-CMIV-AGPITSNAA \\
\hline Z.mays & LKNAAAGV-SGLNAGNAASI \\
\hline$u m$ & MAR-AQVMLMAVALV-LMLA-AVPRA-AVAI \\
\hline & \\
\hline
\end{tabular}

B

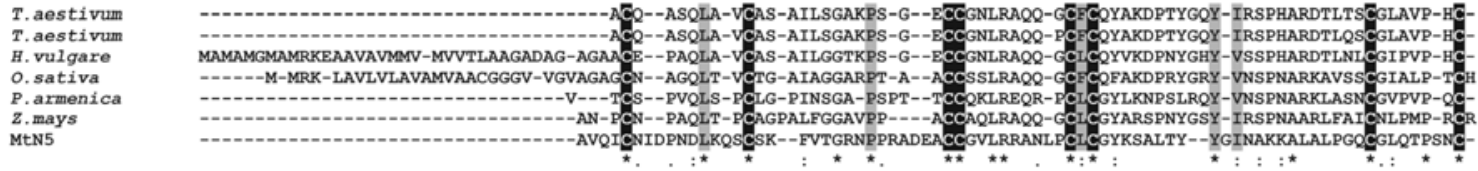

C

Dir1-1 AIDICGMSQDELN-EGKPAVSKENPTSPSQPCCTALQHADFACLCGYKNSPWLGSFVDPELASALPKOCGLANAPTC

MTN5 AVQICNIDPNDLKQSCSKFVTGRNPPRADEACCGVLRRANLPCICGYKSA--LTYYGINAKKALALPGQCGLQTPSNC

Fig. 1. Comparison of the amino acid sequences of Medicago truncatula N5 protein and representative members of lipid transfer protein (LTP) 1 and LTP2 families. The sequence of the proteins were obtained from SWISS-PROT and aligned with Clustal W (Thompson et al. 1994). The black boxes indicate the eight-cysteine motif, whereas the residues that are fundamental for the folding and the lipid-binding activity are boxed in light gray. A, Multiple sequence alignment between members of the LTP1 family and MtN5. The data bank accession numbers of the proteins are the following: Cicer arietinum (O23758), Phaseolus vulgaris (O24440), Prunus dulcis (Q43017), P. domestica (P82534), P. armeniaca (P81651), Malus domestica (Q9M5X7), Nicotiana tabacum (Q42952), Lycopersicon esculentum (P93224), Gossypium hirsutum (Q9FVA5), Gerbera hybrida (Q39794), Helianthus annuus (Q39950), Brassica napus (Q42614), Arabidopsis thaliana (Q42589), Zea mays (P19656), and Triticum aestivum (Q8GZB0). B, Multiple sequence alignment between members of the LTP2 family and MtN5. The data bank accession numbers of the proteins are listed as follows: T. aestivum (P82900 and P82901), Hordeum vulgare (P20145), Oryza sativa (P83210), P. armeniaca (P82353), and Z. mays (P83506). C, Pairwise alignment between MtN5 and A. thaliana DIR1 (Q8W453); *, residues identical in all sequences; :, for conserved substitutions; ., for semiconserved substitutions. 
(Fig. 1A) whereas the overall homology is higher with type 2 LTP (21\% identity, 38\% similarity) (Fig. 1B). In addition to the eight strictly conserved cysteines, MtN5 also displays several residues (i.e., L12, P25, L44, Y54, and I56), which were demonstrated to be crucial for the folding and the lipid-binding activity of LTP2 (Fig. 1B) (Cheng et al. 2007). Interestingly, the alignment between DIR1, which was recently defined as a new type of LTP (Lascombe et al. 2008), and MtN5 (Fig. 1C), highlighted a higher homology degree (37\% identity, 83\% similarity) with respect to the other type 2 LTP, even though the pI of DIR1 is acidic (pI 4.5) whereas MtN5 is a basic protein (pI 9.0).

Phylogenetic analysis was conducted to assess the relationships between MtN5 and several well characterized LTP from other plant species, also including A. thaliana DIR1 (Supplementary Fig. 1). The phylogenetic tree suggests that the proteins analyzed could be divided into three groups, two of which consist of family 1 and family 2 LTP. MtN5 and DIR 1 grouped independently from the two major LTP families, despite the fact they display a higher degree of homology with family 2 LTP.

\section{MtN5 expression and purification.}

In order to further characterize MtN5, the nucleotide sequence encoding for the mature protein tagged with six His residues at the N-terminus was cloned in the pET12b vector and expressed in E. coli BL21 (DE3) pLysS. The (His) ${ }_{6}$-tag enables affinity purification on the Ni-NTA affinity column. Recombinant MtN5 was purified from inclusion bodies using strong de-
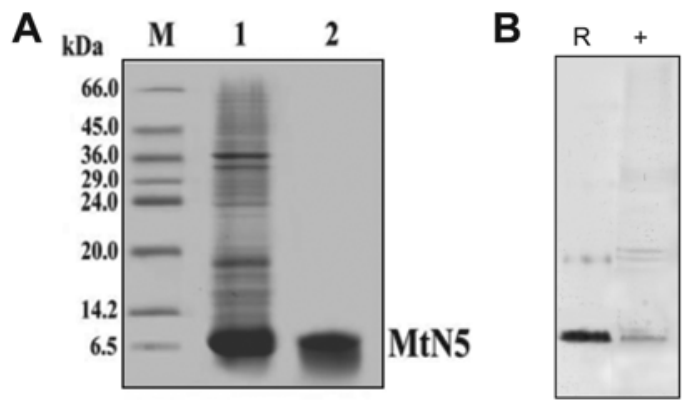

Fig. 2. Medicago truncatula N5 protein expression and purification. A, Expression and purification of recombinant MtN5 protein (Coomassie staining). Lane1: Escherichia coli BL21 (DE3) pLysS lysate. Lane 2: Affinity chromatography-purified recombinant MtN5. B, Western blot analysis of crude protein extract from $M$. truncatula-nodulated roots (R); +, purified recombinant MtN5 protein; M, molecular weight marker.

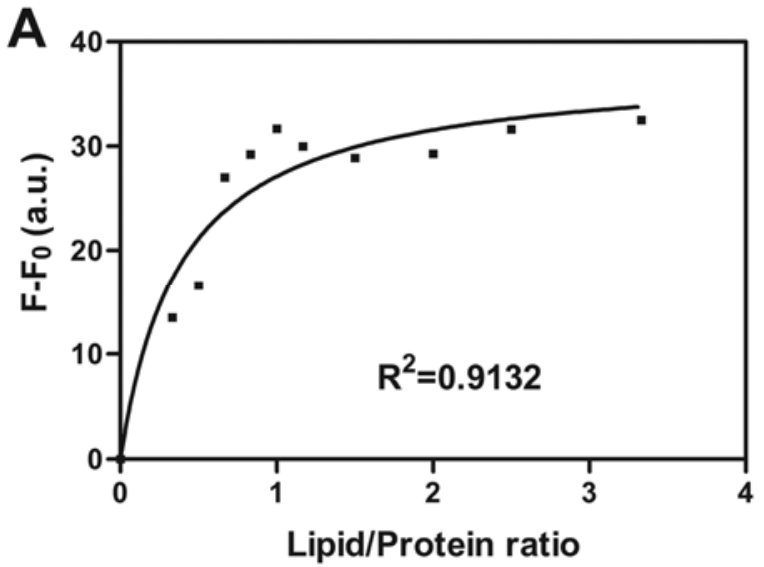

naturing conditions and applying a refolding protocol in column, by removing the denaturing agent through a linear gradient (Fig. 2A). In addition to carrying out the in vitro tests, we also used the recombinant protein to produce polyclonal antibodies in rabbit. Such an antibody detects, in protein crude extracts of nodulated roots, a single principal band of approximately the same apparent molecular mass as the purified recombinant protein (Fig. 2B).

\section{Biochemical characterization of MtN5.}

Lipid binding by plant LTP can be assessed by means of equilibrium titration experiments using lipids as substrates (Gomar et al. 1996; Lascombe et al. 2008). The binding of lysolipids induces the enhancement of intrinsic fluorescence emitted by aromatic side chains which are affected by the hydrophobic environment (Crimi et al. 2006). To probe the lipidbinding capacity of MtN5 protein, lyso-phosphatidylcholines (LPC) with various fatty acids chain lengths (LPC-C12, LPCC16, and LPC-C18) were used. MtN5 presents, in its amino acid sequence, three tyrosine residues (Y47, Y53, and Y54) and displays a maximum of fluorescence emission at $305 \mathrm{~nm}$ in an aqueous environment. Upon the binding of LPC-C12 and LPC-C16, the MtN5 maximum of fluorescence emission at $305 \mathrm{~nm}$ remained unchanged; however, the relative fluorescence intensity increased as a function of lipid concentration up to $12 \mu \mathrm{M}$ (Supplementary Fig. 2). The addition of Tween 20 to MtN5 in solution did not affect the fluorescence emission spectrum (data not shown), thus demonstrating that the changes in fluorescence intensity observed after the addition of lyso-phosphatidylcholines were due to a specific lipid-protein interaction. The fitting of the titration points (i.e., relative fluorescence intensity at $305 \mathrm{~nm}$ versus lipid/protein ratio) using a noncooperative binding model revealed that the saturation of the lipid-binding sites was reached when the molar ratio between MtN5 and the ligand was approximately 1:1 for both LPC-C12 and LPC-C16 (Fig. 3A and B). In the binding assay carried out with LPC-C18, MtN5 did not display the increase in the intrinsic fluorescence emission observed when the ligands were LPC-C12 and LPC-C16 (data not shown). These findings indicate that MtN5 protein possesses a lipid-binding activity, as observed in several other members of the plant LTP superfamily.

\section{MtN5 exhibits antimicrobial activity in vitro.}

To examine whether the recombinant MtN5 exerts antimicrobial activity, we tested its action on Xanthomonas campestris pv. alfalfa, a bacterial pathogen that infects the aerial parts

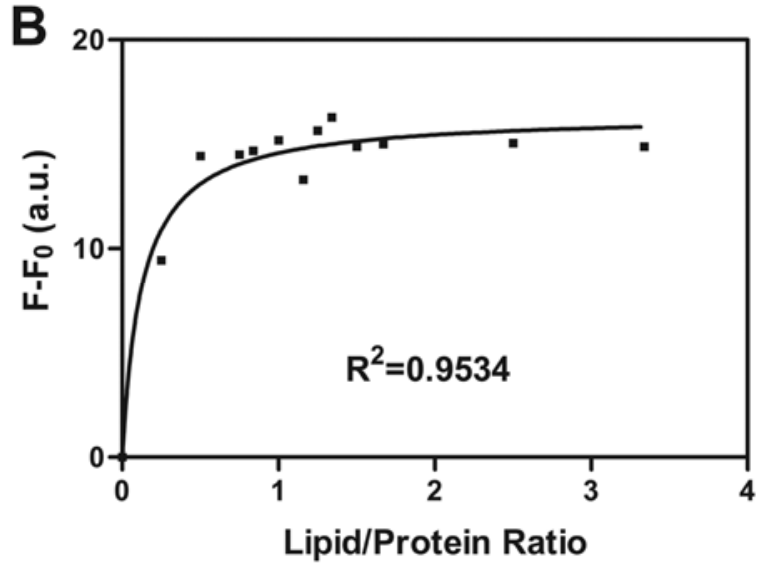

Fig. 3. Lipid-binding assays. A, Titration points, increasing in fluorescence intensity ( $\mathrm{F}$ to $\left.\mathrm{F}_{0}\right)$ at $305 \mathrm{~nm}$ versus LPC-C12/protein molar ratio and $\mathbf{B}$, LPC$\mathrm{C} 16 /$ protein molar ratio. The fitting curves of the titration points were obtained with a noncooperative binding model. F: fluorescence emission of the Medicago truncatula N5 protein in the presence of lipids; $\mathrm{F}_{0}$ : fluorescence emission of MtN5. 
of Medicago spp.; on Fusarium semitectum, a soilborne fungus which attacks the root apparatus of Medicago plants; and on $S$. meliloti, the natural host of M. truncatula. The action of MtN5 on the growth of the microorganisms tested was compared with that exerted by the same amounts of bovine serum albumin (BSA). The growth of $F$. semitectum in the presence of MtN5 was slower than untreated culture, already at low concentrations (starting from $0.5 \mu \mathrm{M}$ ), and the effect was dependent on the amount of protein added to the medium up to a concentration of $10 \mu \mathrm{M}$ (Fig. 4A). MtN5 also affects $X$. campestris growth; the inhibition of bacterial growth displays a dose-dependent trend and the effects were detectable starting from $0.4 \mu \mathrm{M}$ (Fig. 4B). Furthermore, MtN5 showed an antibiotic activity also against $S$. meliloti, which is the natural symbiont of Medicago plants (Fig. 4C). Interestingly, the inhibitory effect against Rhizobium spp. was observed at concentrations higher $(>1 \mu \mathrm{M})$ than those necessary to inhibit the growth of the two pathogens.
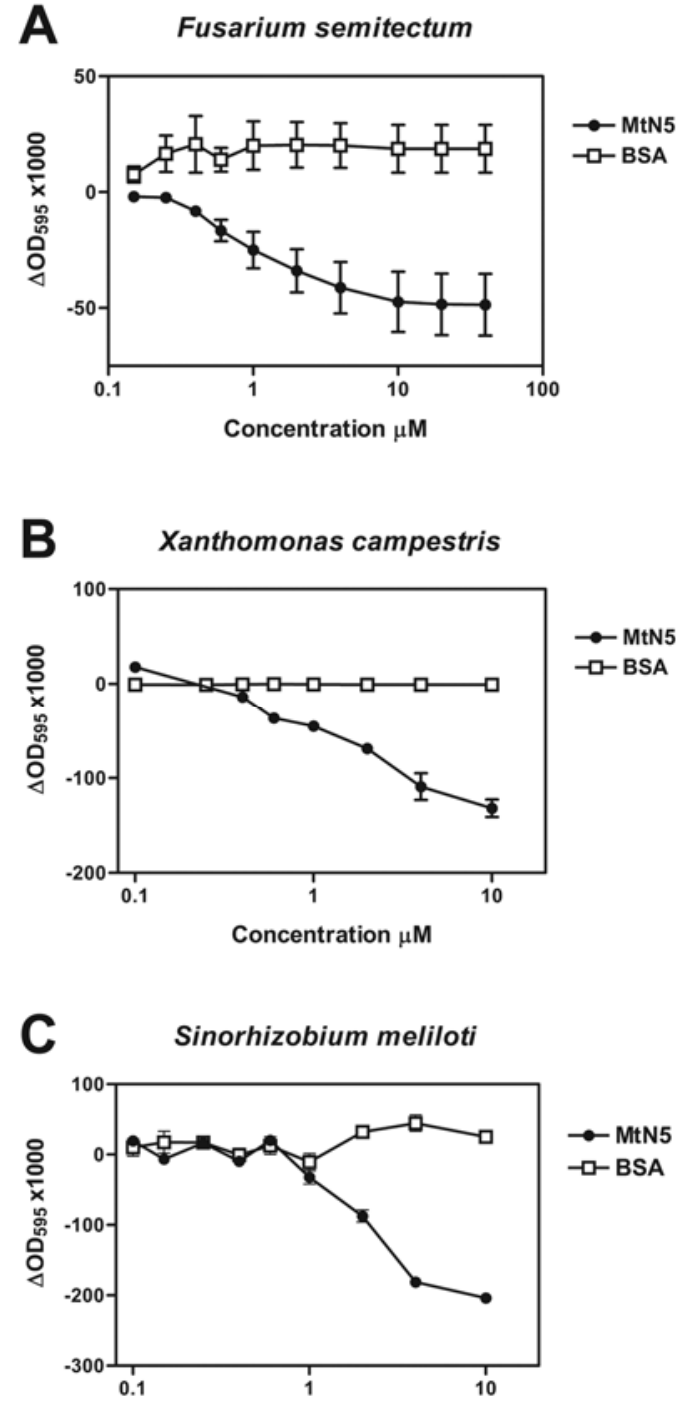

Fig. 4. In vitro antimicrobial assays. The microbial growth was determined by measuring the absorbance at $595 \mathrm{~nm}$ of the microorganism suspensions after $72 \mathrm{~h}$ of incubation in microplates with different concentrations of the Medicago truncatula N5 protein. A, Effect of MtN5 on Fusarium semitectum growth. B, Effect of MtN5 on Xanthomonas campestris growth. C, Effect of MtN5 on Sinorhizobium meliloti growth. $\Delta \mathrm{OD}_{595}$ represents the difference in the optical density between the untreated and the treated samples. The effect of MtN5 on microorganism growth was compared with that of bovine serum albumin (BSA).

\section{Root MtN5 expression is induced after $F$. semitectum infection.}

In order to test whether MtN5, like other plant LTP, is upregulated in infected tissues, the expression pattern of MtN5 protein was investigated in plants inoculated with either $F$. semitectum ISCF20a (Zaccardelli et al. 2006) or X. campestris pv. alfalfae. F. semitectum is often isolated from plants with complex diseases: in legume crops $F$. semitectum may cause seed rot, collar rot and root rot (Zaccardelli et al. 2006). The roots were inoculated with two different concentrations of the pathogenic fungus (10 and 50\%, vol/vol) and collected $48 \mathrm{~h}$ after the infection. In nonnodulated plants, the expression of MtN5 in the root apparatus was elicited by F. semitectum at both concentrations (Fig. 5). However, in plants treated with $F$. semitectum at $50 \%$, the MtN5 level that resulted was lower than that obtained in the plants infected with the fungus at $10 \%$. In nodulated roots, we observed a similar increase in the amount of protein upon treatment with 10 and $50 \%$ of fungus compared with nodulated roots of untreated plants. In addition, the increase in MtN5 level was restricted to root apparatus, because the protein was not detected in the shoots of infected plants (data not shown).

In $M$. truncatula plants inoculated with the bacterial pathogen $X$. campestris, MtN5 protein was detected in neither the infected shoot tissue nor the root tissue of both nonnodulated plants and nodulated plants (data not shown). In addition, MtN5 protein was not elicited in the root tissue even by wounding (data not shown).

Considering these findings, we can infer that MtN5 is a rootspecific protein which is upregulated in response to microorganisms that infect the root apparatuses.

\section{MtN5 is specifically expressed in root nodules during rhizobial symbiosis.}

The expression pattern of MtN5 was evaluated in 40-day-old $M$. truncatula plants by means of quantitative reverse-transcriptase polymerase chain reaction (qRT-PCR). In nodulated plants, the MtN5 gene was highly expressed in the root nodules, where the level of expression was sevenfold higher with respect to the transcript level detected in either nonnodulated

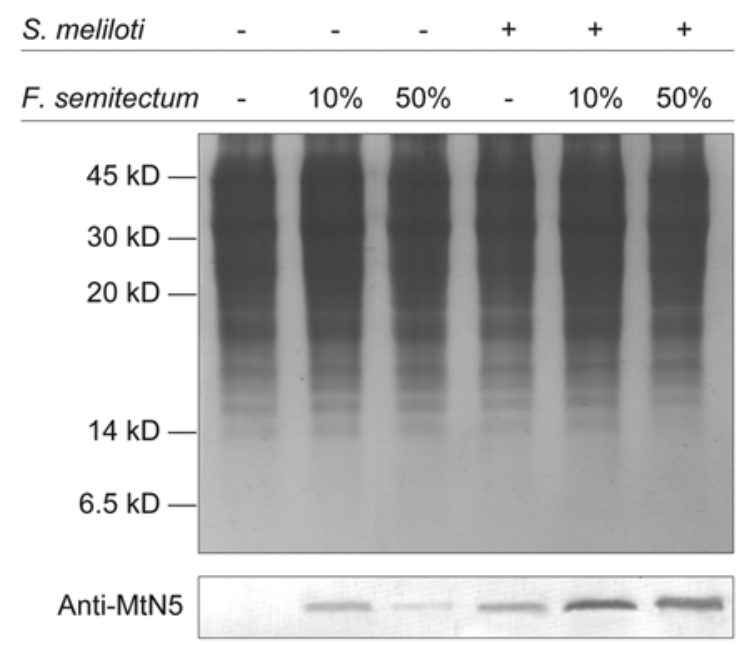

Fig. 5. Medicago truncatula N5 protein expression in root apparatuses of plants infected with Fusarium semitectum. M. truncatula plants (40 days old), either nodulated or nonnodulated, were treated with two different concentrations (10 and $50 \%$, vol/vol) of F. semitectum. Total proteins were extracted from root apparatuses of both infected and noninfected plants and analyzed by Western blot. An equivalent amount of proteins was loaded in each lane, as shown by the Coomassie staining (upper panel). 
roots or in nodulated roots deprived of nodules (Fig. 6A). The aerial part of both nonnodulated and nodulated plants displayed an extremely low level of MtN5 mRNA with respect to root tissue ( 2 and $18 \%$ in nonnodulated plants and nodulated plants, respectively, compared with nonnodulated roots).

We also looked for the presence of MtN5 protein in 40-dayold M. truncatula plants nodulated by $S$. meliloti (Fig. 6B): MtN5 protein was detectable only in root nodules, suggesting that the nodules represent the organs where the protein is preferentially expressed and accumulated.

MtN5 was classified as an early nodulin, whose mRNA is induced well before the onset of nitrogen fixation, maintained in mature nodules (14 days after inoculation), and also expressed in $\mathrm{N}$ fixation-defective Nar nodules (Gamas et al. 1996). On the basis of these findings, it has been proposed that the protein encoded by MtN5 could play a role in root nodule organogenesis rather than in nitrogen fixation (Gamas et al. 1996). We studied the induction kinetic of MtN5 protein during different phases of rhizobia infection (Fig. 6C). Seedlings (7 days old) were microflood inoculated with $S$. meliloti and the roots were collected $0,1,3,4,5$ and 14 days post inoculation (dpi). MtN5 was detected starting from $1 \mathrm{dpi}$ and it reached the highest concentration at $3 \mathrm{dpi}$. These data suggest that MtN5 induction is an early event that might occur before invasion of the root by rhizobia. The MtN5 protein content decreased after $3 \mathrm{dpi}$, and remained stable between 7 and $14 \mathrm{dpi}$ (Fig. 6C).

Overall, these results confirm that MtN5 expression is induced during symbiotic interaction and demonstrate that MtN5 protein is produced in the early phases of $S$. meliloti infection and is localized in the mature nodules.

\section{Silencing and overexpression of MtN5.}

The functional study of MtN5 during the establishment of the symbiosis was carried out by both silencing and overexpression approaches. A hairpin $(h p)$ gene construct designed to silence the endogenous MtN5 was transferred to M. truncatula roots by Agrobacterium rhizogenes-mediated transformation. As negative control, $M$. truncatula plants inoculated with $A$. rhizogenes harboring the empty pBIN19 binary vector were used. A. rhizogenes generates adventitious, genetically transformed roots at the site of inoculation. The transformed roots were selected by growing them on kanamycin, and the transgenic state of adventitious roots was checked by PCR analysis (discussed below) because other laboratories had previously observed that not all M. truncatula hairy roots selected on antibiotic-containing medium were transformed (Limpens et al. 2004; Huo et al. 2006). In addition, the effective expression of the $h p$ construct was tested by means of RT-PCR (Fig. 7A).

The expression of the $h p$ construct induced the silencing of the MtN5 gene in the roots (Fig. 7B). The steady-state level of MtN5 mRNA in silenced hairy roots was reduced, on average, by approximately 70 to $75 \%$ when compared with either control noninoculated roots or control nodulated roots deprived of nodules (Fig. 7B). In addition, the MtN5 expression was also evaluated in the nodules, generated on both control and MtN5silenced roots. In silenced nodules, the relative amount of MtN5 mRNA turned out to be reduced by $98 \%$ when compared with control nodules (Fig. 7C). The MtN5-silenced roots were impaired in nodulation, because they developed $50 \%$ fewer nodules with respect to the inoculated control roots (Fig. 7D).

We observed that the presence of the antibiotic kanamycin used as selective agent in the medium somewhat affects the
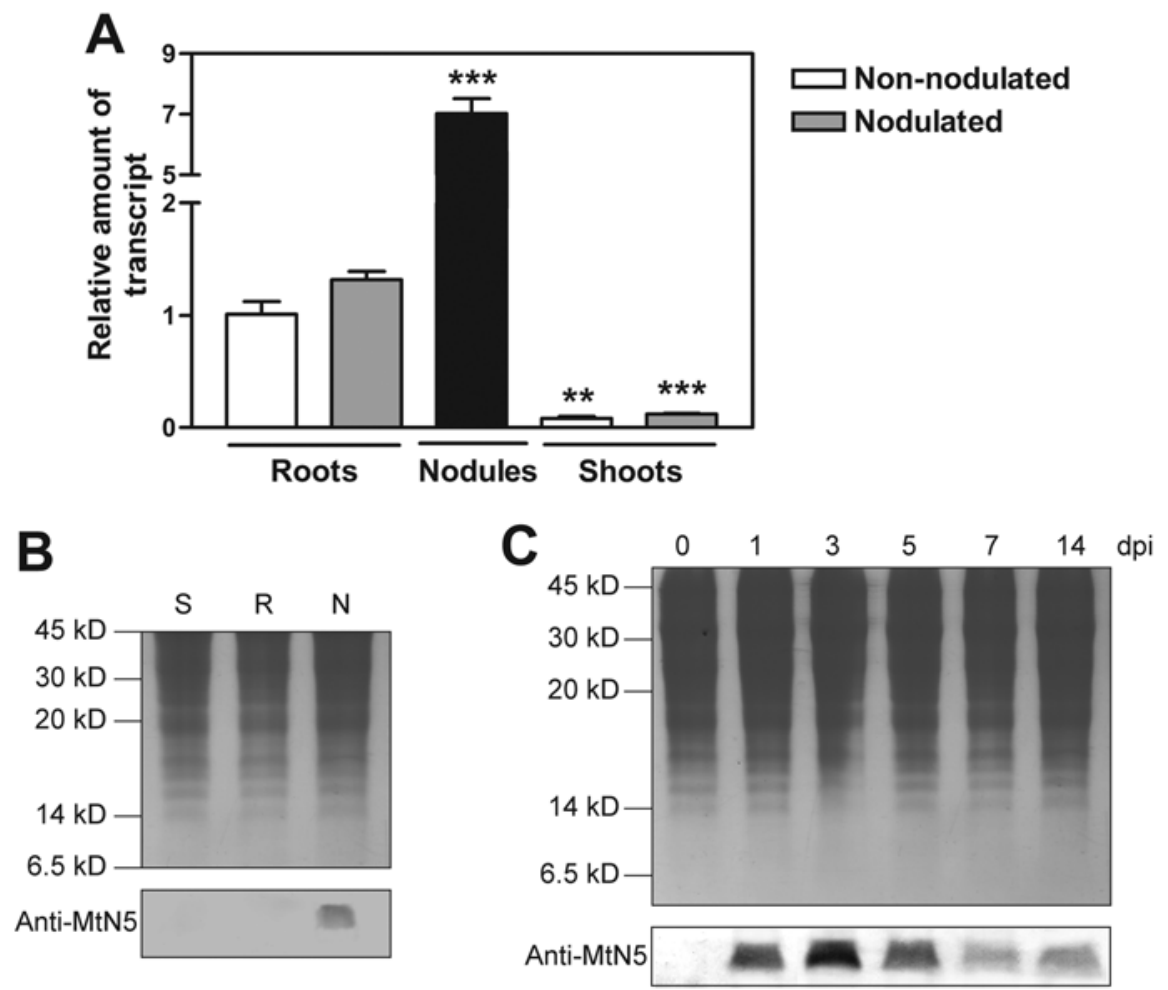

Fig. 6. Expression pattern in Medicago truncatula plants. A, Expression of the M. truncatula N5 gene in roots and shoots of both nonnodulated and nodulated plants and in root nodules was evaluated by quantitative reverse-transcriptase polymerase chain reaction. Total messenger RNA was extracted from 40-day-old plants. The expression levels were normalized using actin as endogenous control gene and the relative expression ratios were calculated using nonnodulated roots as calibrator sample. The values reported are means \pm standard error $(n=3 ; * *, P<0.01$; $* * *, P<0.001)$. B, Western blot analysis of proteins extracted from shoots (S), roots deprived of nodules (R), and nodules (N) of 40-day-old M. truncatula plants. An equivalent amount of proteins was loaded in each lane, as shown by the Coomassie staining (upper panel). C, Western blot analysis of proteins extracted from root apparatuses after microflood inoculation with Sinorhizobium meliloti. Roots were collected 1, 3, 5, 7, and 14 days post inoculation (dpi). An equivalent amount of proteins was loaded in each lane as shown by the Coomassie staining (upper panel). 
general status of the plant and might also impair nodulation. Therefore, we used a different selection approach based on the use of a fluorescent selection marker (Limpens et al. 2004) to confirm the results of MtN5 silencing.

In an independent test, a pBINPLUS (van Engelen et al. 1995) derivative binary vector, named pRedRoot (Limpens et al. 2004), was chosen to harbor the $h p$ gene construct with the aim of silencing MtN5. Approximately 50\% of the roots displayed the red fluorescence due to DsRED1 expression, confirming the transformation efficiency already reported by other groups using the same transformation protocol (Fig. 8A and B) (Limpens et al. 2004; Huo et al. 2006). Only the nodules present on roots expressing the fluorescent reporter were considered for the analyses (Fig. 8A through F). The number of nodules developed by the silenced roots were reduced by approximately $80 \%$ when compared with control adventitious roots, generated by transformation with the empty pRedRoot vector (Fig. 8A, B, E, F, and G).

On the other hand, when roots were transformed with the $35 S:: M t N 5$ construct, the MtN5 transcript level of transgenic adventitious roots was approximately sevenfold higher than control adventitious roots (Fig. 8H) and they developed approximately $300 \%$ more nodules with respect to control roots (Fig. 8C, D, E, F, and G).

Nodules developed by MtN5hp and $35 S:: M t N 5$ transgenic roots appeared, at maturation, to be morphologically similar and of approximately the same size; in addition, nodules were all apparently functional because they exhibited the typical red color due to the presence of leghemoglobin.

\section{DISCUSSION}

Plants belonging to the Leguminoseae family are able to establish a symbiotic association with soilborne bacteria, called rhizobia. This mutualistic relationship leads to the development of a new organ, the root nodule. The symbiosis starts with an exchange of signals between the host plants and the symbiont. The flavonoids exuded from the roots act on rhizobia, inducing the synthesis of Nod factors, whose perception results in the activation of a signaling cascade and the induction of symbiosis-specific host plant genes. This class of genes, named nodulins, is subdivided on the basis of the timing of their expression into early and late nodulins. The early nodulins are expressed before the onset of nitrogen fixation and are considered to be involved in both the infection process and the organogenetic plant response. The late nodulins are induced in mature nodules and are related to the nitrogen-fixing metabolism and root nodule physiology. In recent years, many nodulin genes have been isolated from different leguminous plants. Mergaert and co-workers (2003) identified a gene family (NCR) composed of 300 members encoding for small (60 to 90 residues), cysteine-rich proteins, which are upregulated during rhizobial infection. On the basis of their specific temporal and spatial expression profile, it has been proposed that they participate in nodule development (Mergaert et al. 2003).

MtN5 codes for a cysteine-rich protein, which has been classified as early nodulin because it is induced during the early phases of the symbiotic association between M. truncatula and
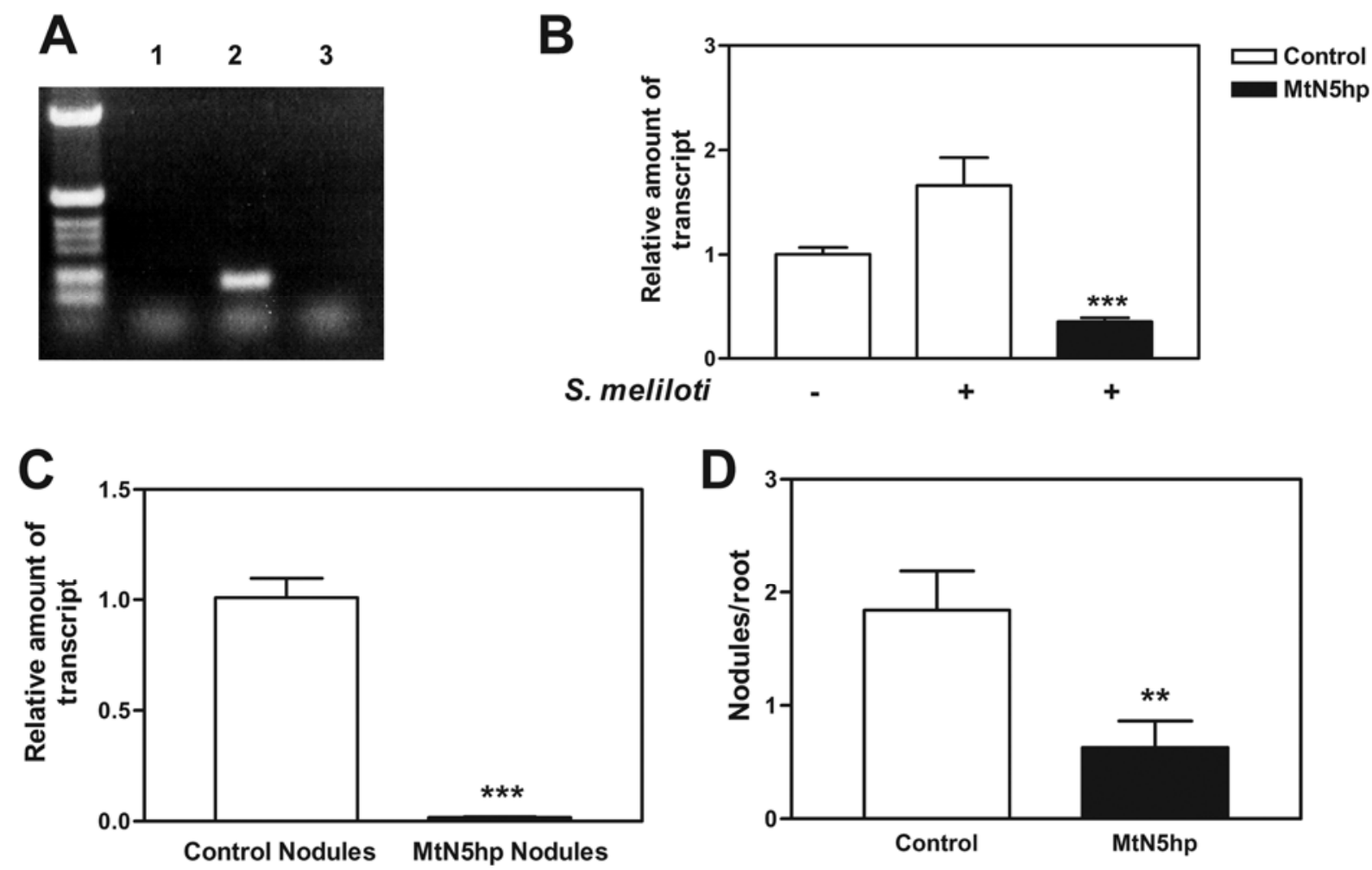

Fig. 7. Medicago truncatula $N 5$ gene silencing in transgenic M. truncatula roots. A, Expression of the MtN5 hairpin ( $h p)$ gene construct in hairy roots. Agarose gel electrophoresis of reverse-transcriptase polymerase chain reaction (RT-PCR) product obtained from total RNA extracted from control roots (lane 1) and from MtN5-silenced roots (lane 2). Lane 3: no-template control. B, Expression of MtN5 in hairy roots. The expression level was evaluated by means of quantitative RT-PCR in MtN5hp roots inoculated with rhizobia and in control roots, both noninoculated (-) and inoculated (+). The expression levels were normalized using actin as endogenous control gene. The relative expression ratios were calculated using noninoculated control root as calibrator sample. The values reported are means \pm standard error $(\mathrm{SE})(n=3$; ***, $P<0.001)$. C, Expression of $M t N 5$ in root nodules generated on control and $N 5 h p$ hairy roots. The expression levels were normalized using actin as endogenous control gene. The relative expression ratios were calculated using control nodule as calibrator sample. The values reported are means $\pm \mathrm{SE}(n=3 ; * * *, P<0.001)$. D, Number of nodules per root. The values reported are means $\pm \mathrm{SE}(n=18 ; * *$, $P<0.01)$. Control: hairy roots generated by Agrobacterium rhizogenes carrying an empty pBIN19 vector; MtN5hp: hairy roots generated by A. rhizogenes carrying the recombinant pBIN19 vector containing the $h p$ construct. 
S. meliloti (Gamas et al. 1996; El Yahyaoui et al. 2004). MtN5 was annotated as a putative plant LTP because of the presence of the typical eight-cysteine motif in its amino acid sequence (El Yahyaoui et al. 2004). Plant LTP are grouped in two classes, LTP1 and LTP2, on the basis of their molecular mass, which is approximately 9 and $7 \mathrm{kDa}$ for LTP1 and LTP2, respectively (Yaets and Rose 2008). MtN5 protein has a molecular mass of approximately $8 \mathrm{kDa}$ and displays a higher sequence similarity with members of the LTP2 family than with members of the LTP1 family. Site-directed mutagenesis studies carried out on LTP2 from Oryza sativa individuated a set of amino acids that are fundamental for the tertiary structure and the lipid-binding activity of this protein (Cheng et al. 2007). These amino acids are conserved in MtN5 sequence, strengthening its resemblance with type 2 LTP. Notably, MtN5 shows a higher sequence homology with Arabidopsis thaliana DIR1 (37\% identity, 83\% similarity), which was recently proposed as a peculiar LTP2 (Lascombe et al. 2008). Despite being closer to LTP2, the phylogenetic analysis shows that MtN5 and DIR1 group independently from the two major LTP families.

Although plant LTP have not yet been provided with a clear biological role, their characteristic biochemical properties, such as the ability to bind lipids in vitro (Kader 1996) and to inhibit microbial growth in vitro, have been associated with a possible defensive role of these proteins in vivo (Van Loon and Van Strien 1999).

The data presented here demonstrate that, in addition to sharing sequence similarities with LTP, MtN5 exhibits biochemical features typical of this protein family because it is able to bind lysophospholipids; possesses a slight antimicrobial activity in vitro against $X$. campestris, $F$. semitectum, and $S$. meliloti; and is upregulated upon microorganism infection.

The specific role of these cysteine-rich proteins in the rhizobial infection and nodule development is not fully elucidated. The upregulation of these cysteine-rich proteins has been explained as either a response that limits rhizobia invasion and spreading or a mechanism that protects root nodules from nonsymbiotic microorganisms (Gamas et al. 1998; Mergaert et al. 2003; El Yahyaoui et al. 2004; Chou et al. 2006). It was shown that, during the early stages of nodule formation, the Nod factors can elicit reactions that are similar to those induced by the match with pathogens (e.g., production of reactive oxygen species, phytoalexins, and PR proteins) (Santos et al. 2001; Mithöfer, 2002; El Yahyaoui et al. 2004; Mitra and Long 2004). However, it was proposed that these responses most likely are attenuated by bacterial effectors (e.g., lipopolysaccharides and exopolisaccharides) (Mithöfer 2002; Scheidle et al. 2005; Tellstrom et al. 2007). Furthermore, it was observed that the induction of plant defense responses is involved in autoinhibitory control of the nodule number (van Brussel et al. 2002).

MtN5 induction is an early event of the rhizobial infection and was shown to be dependent on Nod factor signaling; it has been observed that, in $M$. truncatula plants grown in aeroponic conditions, a 24-h treatment with Nod factors induces MtN5 gene expression (Gamas et al. 1996). However, it has been reported that MtN5 is not expressed in the M. truncatula $n f p$ mutant impaired in Nod factor perception (El Yahyaoui et al 2004) and that the inoculation of roots with the $S$. meliloti nod $A^{-}$mutant, defective in Nod factor synthesis, causes only a transient induction of MtN5 expression between 3 and $24 \mathrm{~h}$ (Gamas et al. 1996; El Yahyaoui et al 2004). Our findings confirm the rapid accumulation of MtN5 protein in the root tissue during the early stages of rhizobial invasion. Furthermore, we have shown that, in the late phases of the symbiosis, MtN5 is predominantly localized within the nitrogen-fixing nodules. This expression pattern suggests that the role of MtN5 in the symbiosis might be either to protect mature nodules against
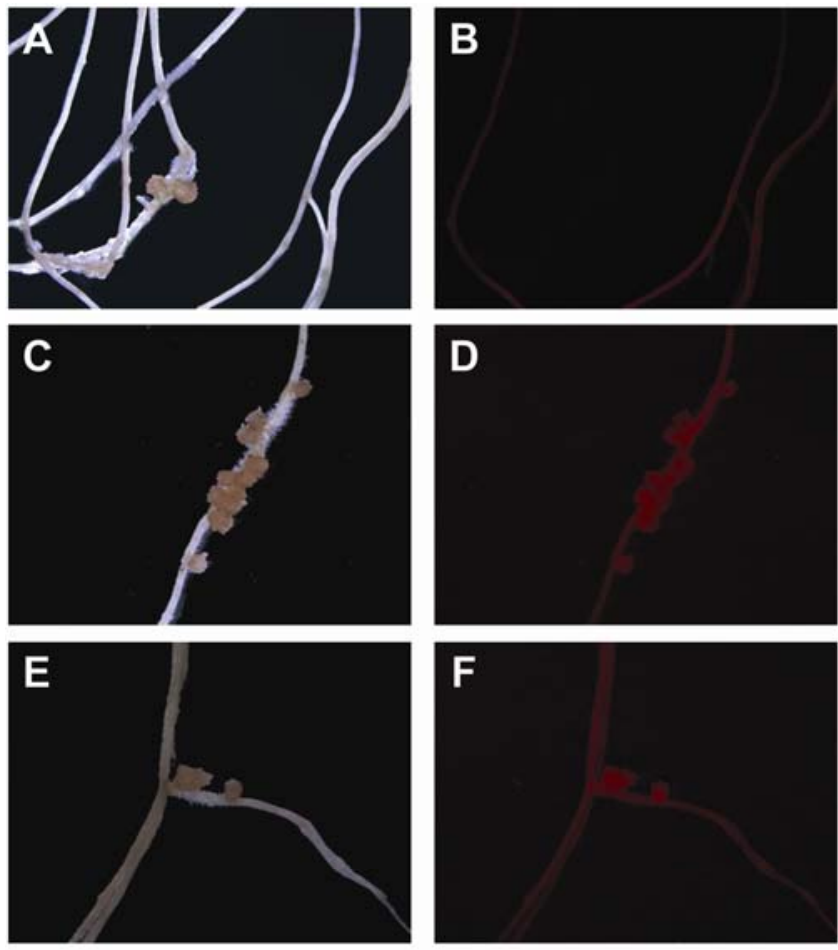

G

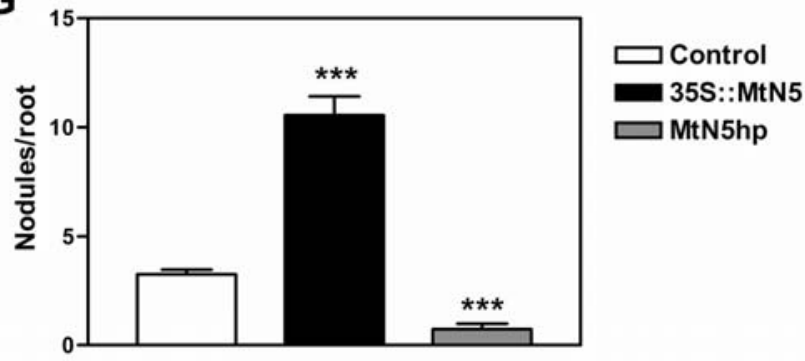

H

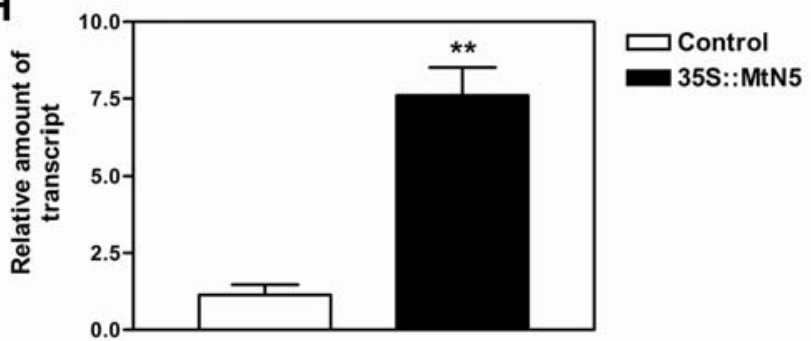

Fig. 8. Effects of silencing and overexpression of the endogenous Medicago truncatula N5 gene. M. truncatula hairy roots transformed with MtN5hp harbored in the pRedRoot binary vector A, Bright-field picture. B, DsREDI fluorescence (red fluorescence). M. truncatula hairy roots transformed with $35 S:: M t N 5$ gene construct harbored in the pRedRoot binary vector. C, Bright-field picture. D, DsRED1 fluorescence (red fluorescence). M. truncatula hairy roots produced by Agrobacterium rhizogenes harboring the empty pRedRoot binary vector. E, Bright field. F, DsREDI fluorescence (red fluorescence). G, Number of nodules per root. The values reported are means \pm standard error (SE); ***, $P<0.001$. H, Expression of MtN5 in hairy roots transformed with $35 S:: M t N 5$ gene. The expression level was evaluated by means of quantitative reverse-transcriptase polymerase chain reaction in both $M t N 5$-overexpressing and control roots inoculated with rhizobia and deprived of nodules. The expression levels were normalized using actin as endogenous control gene. The relative expression ratios were calculated using inoculated control root as calibrator sample. The values reported are means \pm SE $(n=3$; **, $P<0.01)$. Control: hairy roots generated by $A$. rhizogenes infection, carrying an empty pRedRoot vector. $35 \mathrm{~S}:: \mathrm{MtN} 5$ : hairy roots generated by A. rhizogenes infection, carrying the recombinant $\mathrm{pRedRoot}$ vector containing the gene construct for the overexpression. MtN5hp: hairy roots generated by A. rhizogenes infection, carrying the recombinant pRedRoot vector containing the $h p$ gene construct. 
pathogens or to promote nodule development, rather than to limit rhizobia infection. Indeed, the suppression of MtN5 results in a reduced nodulation whereas its overexpression increases the number of nodules produced by $S$. meliloti. Although MtN5 exhibits an inhibitory effect on $S$. meliloti growth in vitro, the results of MtN5 silencing and overexpression rule out a putative role of MtN5 in the limitation of rhizobia infection and spreading. This is the first demonstration that a gene coding for a lipid transfer protein is required for the successful invasion of host roots by rhizobia. Our results also concur with the fact that MtN5 does not belong to those genes that are downregulated in the supernodulating $M$. truncatula mutant TIR122 (El Yahyaoui et al. 2004).

The timing of expression of MtN5 might indicate a putative role of this protein in the early phases of symbiotic interaction. Interestingly, phospholipids also seem to act as signal molecules in the establishment of rhizobial symbiotic association (Charron et al. 2004). More recently, it has been shown that lyso-phosphatidylcholine is involved in the signaling pathway of the arbuscular mycorrhizal symbiosis (Drissner et al. 2007). We have demonstrated here that MtN5 is able to bind lysolipids and, thus, might be involved in lipid-mediated signaling processes during symbiosis. The apoplastic localization of MtN5 is in accordance with a possible role in the exchange of signals between the host plant and the Rhizobium sp. It is remarkable that MtN5 shares a high degree of homology with DIR1 an LTP that takes part in the signaling cascade activated by pathogen infection in A. thaliana. However, considering that MtN5 is also present in mature nodules, it cannot be excluded that it might have a role in later phases of nodule development too.

There is experimental evidence suggesting that LTP could also function as lipid carriers from the intracellular compartment toward the apoplast; for instance, during the synthesis of the cuticle (Cameron et al. 2006). Following from this idea, we can speculate that MtN5 might also be involved in the targeting of new lipidic materials during the stages of both infection thread and symbiosome development that require reorganization and de novo formation of membranes.

The results herein presented also demonstrate that the accumulation of MtN5 protein is rapidly induced by the infection of a fungal root pathogen. The induction of MtN5 protein upon F. semitectum infection might suggest that MtN5 can exert a defensive role against fungi that attack the root apparatus. It was shown that plant LTP can exert their antimicrobial activity either via permeabilization of a pathogen's plasma membrane (Regente et al. 2005; Diz et al. 2006) or as lipid sensors in defense signal pathways, as is the case with $A$. thaliana DIR1 (Maldonado et al. 2002). Lipid molecules, such as oxolipins (JA), phosphatidic acid, and $\mathrm{N}$-acylethanolammines, are produced by plants as a consequence of pathogen attacks and act as second messengers in plant defense signaling (Wasternack and Parthier 1997; Chapman 2000; Munnik 2001). Because MtN5 is not induced by either $X$. campestris infection in vivo or wounding (data not shown), our findings also suggest that the expression of MtN5 protein is not a generic response to biotic stresses but is restricted to those microorganisms that interact with plants at root level. The persistence of MtN5 in mature nodules could represent a form of rapid protection of nodules against fungal attacks.

Further studies are needed to get a clear picture of the role played by this gene during symbiotic interaction between $M$. truncatula and S. meliloti. In particular, it would be interesting to study the localization of MtN5 both within the root nodule and in the root tissue during the different stages of rhizobia infection, and to identify which phases of the nodulation process MtN5 takes part in.
In conclusion, our results indicate that MtN5 exhibits biochemical features typical of plant LTP and displays similarity to type 2 LTP. Furthermore, we have demonstrated that MtN5 is specifically expressed in root nodules and required for the successful establishment of the symbiotic interaction between M. truncatula and S. meliloti.

Based on the observation that MtN5 is also induced by a pathogenic microorganism, we can speculate that this protein might have a dual function, participating in both the defense of roots and nodules against pathogens and in the establishment of a symbiotic interaction with rhizobia.

\section{MATERIALS AND METHODS}

\section{Bacterial strains.}

S. meliloti 1021 (Meade et al. 1982) was grown at $28^{\circ} \mathrm{C}$ in LBMC medium (tryptone at $10 \mathrm{~g} /$ liter, yeast extract at $5 \mathrm{~g} / \mathrm{liter}$, $\mathrm{NaCl}$ at $10 \mathrm{~g} /$ liter, $2.6 \mathrm{mM} \mathrm{MgSO}_{4}$, and $2.6 \mathrm{mM} \mathrm{CaCl}_{2}$ ) supplemented with streptomycin at $200 \mu \mathrm{g} / \mathrm{ml}$. Agrobacterium rhizogenes ARqua1 (Quandt et al. 1993) was grown at $28^{\circ} \mathrm{C}$ in TY medium (tryptone at $5 \mathrm{~g} /$ liter, yeast extract at $3 \mathrm{~g} / \mathrm{liter}$, and $6 \mathrm{mM} \mathrm{CaCl}_{2}, \mathrm{pH}$ 7.2) supplemented with streptomycin at 100 $\mu \mathrm{g} / \mathrm{ml}$. F. semitectum ISCF20a is a wild-type field isolate (Zaccardelli et al. 2006) and it was grown on solid-medium potato dextrose agar (PDA) (Sigma, St. Louis). X. campestris pv. alfalfae was grown on YDA medium (glucose at $10 \mathrm{~g} / \mathrm{liter}$, yeast extract at $5 \mathrm{~g} /$ liter, peptone at $5 \mathrm{~g} /$ liter).

\section{Construction of recombinant plasmid and protein expression.}

MtN5 coding sequence (accession no. Y15371) was amplified using, as template, cDNA obtained by reverse transcribing mRNA extracted from $M$. truncatula roots. The upstream primer was 5'-CATATGCATCATCATCATCATCACGTTCAAA TATGTAACATAGACCCAAATGAT-3' (NdeI site is underlined and His-tag is in italics) and the downstream primer was 5'-GGATCCTTAACAGTTGGAAGGTGTTTG-3' (BamHI site is underlined). The PCR product corresponding to the coding sequence of mature MtN5 was double digested with NdeI and BamHI, cloned into pET12b (Novagen, Madison, WI, U.S.A.), and checked by sequencing. The recombinant vector pET12N5 was mobilized into the host strain E. coli BL21 DE3 pLysS.

MtN5 protein was purified from inclusion bodies using strong denaturing conditions $(20 \mathrm{mM}$ Tris $\mathrm{HCl}, \mathrm{pH} 8.0 ; 0.5 \mathrm{M}$ $\mathrm{NaCl}$; $5 \mathrm{mM}$ imidazole; and $6 \mathrm{M}$ guanidine hydrochloride) and loaded on a Hi-trap column. MtN5 was refolded, applying a linear gradient from 6 to $0 \mathrm{M}$ guanidine hydrochloride. The recombinant protein was used to produce polyclonal antibodies in rabbit (PRIMM s.r.l.; Milano, Italy).

\section{RNAi plasmid construction.}

The RNAi $h p$ construct was built following the construct design previously described (Pandolfini et al. 2003). The arms of the $h p$ construct consist of two 200-bp-long fragments homologous to the $5^{\prime}$ end of the MtN5 coding sequence from base +93 to +292 of the mRNA sequence (Y15371) placed in inverted orientations. The chimeric gene was cloned into both the pBIN19 and pRedRoot (Limpens et al. 2004) binary vectors and the recombinant plasmids were mobilized into $A$. rhizogenes ARqua1.

In order to build the gene construct for MtN5 overexpression, the coding sequence corresponding to the mature protein was PCR amplified (primers used: 5'-GGTACCATGGCACAT TCTCAGGGCAA-3' and 5'-GGATCCTTAACAGTTGGAAG GTGTTTG-3'), subcloned in pGemT (Promega Corp., Madison, WI, U.S.A.), and checked by sequencing. The MtN5 coding region was KpnI-BamHI cloned in pRedRoot in between the 
constitutive promoter $35 S$ from Cauliflower mosaic virus and the nopoline synthase terminator sequence. The recombinant vector was mobilized into A. rhizogenes ARqua1.

\section{Plant growth and rhizobia inoculation.}

$M$. truncatula $\mathrm{cv}$. Jemalong seeds were scarified and sterilized in $5 \%$ commercial bleach for 3 min. Seeds were germinated on $0.8 \%$ agar plates in a growth chamber at $25^{\circ} \mathrm{C}$ for 7 days. Inoculation experiments were carried out using plants grown in pots as previously described (Pii et al. 2007). For the time course assay, germinated seedlings of $M$. truncatula were placed in square petri plates containing slanted BMN agar medium (Engstrom et al. 2002) supplemented with $0.1 \mu \mathrm{M} \mathrm{L}$ $\alpha$-2-aminoethoxyvinyl glycine (AVG). The plates were kept vertically in a growth chamber at $25^{\circ} \mathrm{C}$ and a regimen of $10 \mathrm{~h}$ of light and $14 \mathrm{~h}$ of darkness. Seven days after germination, seedlings were microflood inoculated. Bacteria were grown overnight in liquid LBMC medium, collected by centrifugation, and suspended in $10 \mathrm{mM} \mathrm{MgSO}_{4}$ to an optical density at $600 \mathrm{~nm}$ of 0.2 . Microflood inoculation was performed by placing five drops $(0.5 \mu \mathrm{l})$ of bacterial suspension on the surface of the root. Root apparatuses were collected 1, 3, 5, 7, and 14 dpi.

\section{Plant infection.}

F. semitectum strain ISCF 20 (Zaccardelli et al. 2006) was grown on solid-medium PDA (Sigma) for a week. Ten plugs (6 $\mathrm{mm}$ in diameter) excised from the margin of the fungus colony grown in the petri plate were transferred to an Erlenmeyer flask containing $270 \mathrm{~g}$ of sterile sand, $30 \mathrm{~g}$ of corn meal, and $60 \mathrm{ml}$ of water. After incubation for 3 weeks at $25^{\circ} \mathrm{C}$, the fungal suspension was diluted at 10 and $50 \%$ (vol/vol) with double-sterilized soil. At 30 days after rhizobia inoculation, the plants, grown on sand and perlite as previously described (Pii et al. 2007), were transferred to pots containing double-sterilized soil at the bottom; the root apparatuses were covered with the diluted fungal suspension. Plants were collected $48 \mathrm{~h}$ after infection for further analysis.

\section{Plant transformation.}

Transformation with A. rhizogenes ARqual was performed as previously described (Boisson-Darnier et al. 2001). Plants infected with ARqua1 were kept in square petri dishes containing Fåhraeus Modified Medium ( $1 \mathrm{mM} \mathrm{CaCl}, 0.5 \mathrm{mM}$ $\mathrm{MgSO}_{4}, 0.7 \mathrm{mM} \quad \mathrm{KH}_{2} \mathrm{PO}_{4}, 0.8 \mathrm{mM} \mathrm{Na}_{2} \mathrm{HPO}_{4}, 0.5 \mathrm{mM}$ $\mathrm{NH}_{4} \mathrm{NO}_{3}, 50 \mu \mathrm{M}$ FeNaEDTA, $\mathrm{MnSO}_{4}, \mathrm{CuSO}_{4}, \mathrm{ZnSO}_{4}, \mathrm{H}_{3} \mathrm{BO}_{3}$, and $\mathrm{Na}_{2} \mathrm{MoO}_{4}$ each at $0.1 \mathrm{mg} /$ liter) for approximately 3 weeks. When the binary vector employed in the transformation was pBIN19, FMM was supplemented with kanamycin at $50 \mu \mathrm{g} / \mathrm{ml}$ for transformants selection. Well-developed hairy roots were analyzed by PCR for the presence of the $h p$ gene construct. Approximately $95 \%$ of the roots tested were positive for the gene construct insertion. The expression of the $h p$ construct was checked by RT-PCR. Total RNA was isolated by using RNeasy plant mini kit (Qiagen, Basel, Switzerland). RNA (0.5 $\mu \mathrm{g}$ ) extracted from hairy roots was treated with 0.5 units of RQ1 DNase (Promega Corp.) and then used as a template for a reverse-transcriptase (Superscript II; Invitrogen, Carlsbad, CA, U.S.A.) reaction primed with the oligo-dT. The complementary DNA was amplified with the forward primer 5'-CTGCG GTTACAAGTCCCTAAC-3', annealing on the second arm of the hp construct, and with the primer $5^{\prime}$-GCCAAGCTTGCGC GATGAAATCAAGTATCCAGT-3', complementary to the 5' region of the termination sequence. In the pRedRoot, the antibiotic resistance-encoding gene was replaced with the gene encoding for the fluorescent protein DsRED1, which provides a nondestructive selectable marker that allows the discrimination of transgenic roots from nontransformed ones, thus avoid- ing the use of antibiotics for transgenic root selection (Limpens et al. 2004). Transformed roots were checked using the Leica MZ16F fluorescence microscope using an appropriate filter setting for DsRED1 detection.

For nodulation experiments, plants were nitrogen starved on BMN medium supplemented with $0.1 \mu \mathrm{M}$ AVG for 7 days and microflood inoculated as described above.

\section{qRT-PCR.}

The qRT-PCR analyses were carried out as already described (Pii et al. 2007). The nucleotide sequences of the primers used for the qRT-PCR are the following: MtN5, forward primer $5^{\prime}-\mathrm{A}$ TGGCACATTCTCAGGGCAA-3' and reverse primer 5'-GGT TTCTACCGGTAACGAATT-3'; actin, forward primer 5'-AGA TGCTGAGGATATTCAAC-3' and reverse primer 5'-GTATGA CGAGGTCGGCCAAC-3'. The couple of primers used to analyze the expression of MtN5 in hairy roots was specifically chosen at the $3^{\prime}$ end of the transcript to avoid the amplification of sequences derived from the hp construct itself. The nucleotide sequences of the primers used are the following: forward primer 5'-CTGCGGTTACAAGTCTGCCCTAAC-3' and reverse primer 5'-GCGGATCCTTAACAGTTGGAAGGTGTTT G-3'.

\section{Western blot analysis.}

Total proteins were extracted by grinding frozen tissues in homogenizing buffer $(30 \mathrm{mM}$ Tris- $\mathrm{HCl}, \mathrm{pH} 8.2 ; 50 \mathrm{mM} \mathrm{KCl}$; $0.5 \%$ Tween $20 ; 0.1 \%$ polyvinyl-polypyrrolidone; and $1 \mathrm{mM}$ EDTA) supplemented with $0.04 \%$ 2-mecaptoethanol and $0.1 \%$ plant protease inhibitor cocktail (Sigma). The soluble fraction was obtained by centrifugation at $12,000 \times g$ for $20 \mathrm{~min}$ and the protein concentration was determined by the Bradford method (Bradford 1976). Proteins were acetone precipitated, separated by a $15 \%$ Tris-Tricine sodium dodecyl sulfate polyacrylamide gel electrophoresis, and electroblotted to polyvinylidene diflouride membrane (Amersham, Tokyo). The membrane was probed with the primary polyclonal antibody against MtN5 and, afterward, treated with the alkaline phosphataseconjugated secondary antibody. The immunoblot was placed in the alkaline phosphatase reaction buffer $(100 \mathrm{mM}$ Tris- $\mathrm{HCl}$, $\mathrm{pH} 9.5 ; 100 \mathrm{mM} \mathrm{NaCl}$; and $50 \mathrm{mM} \mathrm{MgCl}_{2}$ ) containing nitro blue tetrazolium and 5-bromo-4-chloro-3-indolyl phosphate as color-developing reagent.

\section{Lipid-binding assay.}

Lipid-binding capacity of MtN5 was assayed by monitoring tyrosine fluorescence. MtN5 protein was dissolved at a suit-

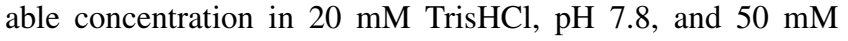
$\mathrm{NaCl}$. Changes in fluorescence intensity were measured at $25^{\circ} \mathrm{C}$ with a Jasco FP-777 spectrofluorimeter using an excitation wavelength at $275 \mathrm{~nm}$ and recording emission between 280 and $340 \mathrm{~nm}$. Lyso-phosphatidilcholine dissolved in ethanol was added in a stepwise manner and fluorescence changes were measured after 2 min of equilibration.

\section{Antimicrobial activity.}

Antimicrobial activity of the MtN5 protein was assayed by microspectrophotometry on liquid cultures grown in microtiter plates as described previously (Broekaert et al. 1990). Briefly, in a well of a 96-well plate, $50 \mu \mathrm{l}$ of microorganism (X. campestris, $F$. semitectum, and $S$. meliloti) cultures at a concentration of $10^{4} \mathrm{CFU} / \mathrm{ml}$ was mixed with MtN5 recombinant protein at different concentrations. The plates were incubated for $72 \mathrm{~h}$ at a suitable temperature according to the type of microorganism. The antimicrobial effect was estimated as the difference between the optical density, measured at $595 \mathrm{~nm}$, of the treated sample and that of the untreated sample. 


\section{Statistical analysis.}

The mean values \pm standard error are reported in the figures. Statistical analyses were conducted using a Student's $t$ test.

\section{ACKNOWLEDGMENTS}

The work was supported by the Ministry of Agricultural Alimentary and Forest Politics with funds released by C.I.P.E. (Resolution 17/2003). We thank A. Spena for scientific advice, M. Chabaud for kindly providing $A$. rhizogenes ARqua1 strain, and R. Geurts for generously gifting pRedRoot vector.

\section{LITERATURE CITED}

Boisson-Dernier, A., Chabaud, M., Garcia, F., Becard, G., Rosenberg, C., and Barker, D. G. 2001. Agrobacterium rhizogenes-transformed roots of Medicago truncatula for the study of nitrogen-fixing and endomycorrhizal symbiotic associations. Mol. Plant-Microbe Interact.14:695700

Boutrot, F., Chantret, N., and Gautier, M. F. 2008. Genome-wide analysis of the rice and Arabidopsis non-specific lipid transfer protein (nsLtp) gene families and identification of wheat nsLtp genes by EST data mining. BMC Genomics. 9:86.

Bradford, M. M. 1976. A rapid and sensitive method for the quantitation of microgram quantities utilizing the principle of protein-dye binding. Anal. Biochem. 72:248-254.

Broekaert, W. F., Terras, F. R. G., Cammue, B. P. A., and Vanderleyden, J. 1990. An automated quantitative assay for fungal growth inhibition. FEMS (Fed. Eur. Microbiol. Soc.) Microbiol. Lett. 69:55-59.

Buhot, N., Gomès, E., Milat, M. L., Ponchet, M., Marion, D., Lequeu, J., Delrot, S., Coutos-Thévenot, P., and Blein, J. P. 2004. Modulation of the biological activity of a tobacco LTP1 by lipid complexation. Mol. Biol. Cell 15:5047-5052.

Cameron, K. D., Teece, M. A., and Smart, L. B. 2006. Increased accumulation of cuticular wax and expression of lipid transfer protein in response to periodic drying events in leaves of tree tobacco. Plant Physiol. 140:176-183

Cammue, B. P., Thevissen, K., Hendriks, M., Eggermont, K., Goderis, I J., Proost, P., Van Damme, J., Osborn, R. W., Guerbette, F., Kader, J. C., and Broekaert, W. F. 1995. A potent antimicrobial protein from onion seeds showing sequence homology to plant lipid transfer proteins. Plant Physiol. 109:445-455

Chapman, K. D. 2000. Emerging physiological roles for $\mathrm{N}$-acylphosphatidylethanolamine metabolism n plants: Signal transduction and membrane protection. Chem. Phys. Lipids 108:221-230.

Charron, D., Pingret, J. L., Chabaud, M., Journet, E. P., and Barker, D. G. 2004. Pharmacological evidence that multiple phospholipid signaling pathways link Rhizobium nodulation factor perception in Medicago truncatula root hairs to intracellular responses, including $\mathrm{Ca}^{2+}$ spiking and specific ENOD gene expression. Plant Physiol. 136:3582-3593.

Cheng, C. S., Chen, M. N., Lai, Y. T., Chen, T., Lin, K. F., Liu, Y. J., and Lyu, P. C. 2007. Mutagenesis study of rice nonspecific lipid transfer protein 2 reveals residues that contribute to structure and ligand binding. Proteins 70:695-706.

Chou, M. X., Wei, X. Y., Chen, D. S., and Zhou, J. C. 2006. Thirteen nodule-specific or nodule-enhanced genes encoding products homologous to cysteine cluster proteins or plant lipid transfer proteins are identified in Astragalus sinicus L. by suppressive subtractive hybridization. J. Exp. Bot. 57:2673-2685.

Crimi, M., Astegno, A., Zoccatelli, G., and Degli Esposti, M. 2006. Proapoptotic effect of maize lipid transfer protein on mammalian mitochondria. Arch. Biochem. Biophys. 445:65-71.

de Oliveira Carvalho, A., and Moreira Gomes, V. 2007. Role of plant lipid transfer proteins in plant cell physiology - a concise review. Peptides 28:1144-1153.

Diz, M. S., Carvalho, A. O., Rodrigues, R., Neves-Ferreira, A. G., Da Cunha, M., Alves, E. W., Okorokova-Façanha, A. L., Oliveira, M. A., Perales, J., Machado, O. L., and Gomes, V. M. 2006. Antimicrobial peptides from chili pepper seeds causes yeast plasma membrane permeabilization and inhibits the acidification of the medium by yeast cells. Biochim. Biophys. Acta 1760:1323-1332.

Drissner, D., Kunze, G., Callewaert, N., Gehrig, P., Tamasloukht, M. Boller, T., Felix, G., Amrhein, N., and Bucher, M.. 2007. Lyso-phosphatidylcholine is a signal in the arbuscular mycorrhizal symbiosis. Science 318:265-268.

El Yahyaoui, F., Küster, H., Amor, B. B., Hohnjec, N., Pühler, A., Becker, A., Gouzy, J., Vernié, T., Gough, C., Niebel, A., Godiard, L., and Gamas, P. 2004. Expression profiling in Medicago truncatula identifies more than 750 genes differentially expressed during nodulation, including many potential regulators of the symbiotic program. Plant Physiol. 136:3159-3176.

Engstrom, E. M., Ehrhardt, D. W., Mitra, R. M., and Long, S. R. 2002. Pharmacological analysis of Nod factor-induced calcium spiking in Medicago truncatula. Evidence for the requirement of type IIA calcium pumps and phosphoinositide signaling. Plant Physiol. 128:1390-1400.

Gamas, P., de Carvalho Niebel, F., Lescure, N., and Cullimore, J. 1996. Use of a subtractive hybridization approach to identify new Medicago truncatula genes induced during root nodule development. Mol. PlantMicrobe Interact. 9:233-242.

Gamas, P., de Billy, F., and Truchet, G. 1998. Symbiosis-specific expression of two Medicago truncatula nodulin genes, MtN1 and MtN13, encoding products homologous to plant defense proteins. Mol. PlantMicrobe Interact. 11:393-403.

García-Olmedo, F., Molina, A., Segura, A., and Moreno, M. 1995. The defensive role of non-specific lipid-transfer proteins in plants. Trends $\mathrm{Mi}$ crobiol. 3:72-74.

Ge, X., Chen, J., Li, N., Lin, Y., Sun, C., and Cao, K. 2003. Resistance function of rice lipid transfer protein LTP110. J. Biochem. Mol. Biol. 36:603-607.

Gomar, J., Petit, M. C., Sodano, P., Sy, D., Marion, D., Kader, J. C., Vovelle, F., and Ptak, M. 1996. Solution structure and lipid binding of a nonspecific lipid transfer protein extracted from maize seeds. Protein Sci. 5:565-577

Hoh, F., Pons, J. L., Gautier, M. F., Lamotte, F. D., and Dumas, C. 2005. Structure of a liganded type 2 non-specific lipid-transfer protein from wheat and the molecular basis of lipid binding. Acta Crystallogr. D Biol. Crystallogr. 61:397-406.

Huo, X. Y., Schnabel, E., Hughes, K., and Frugoli, J. 2006. RNAi phenotypes and localization of a protein:GUS fusion imply a role for Medicago truncatula PIN genes in nodulation. J. Plant Growth Regul. 25:156-165.

Iwai, T., Kaku, H., Honkura, R., Nakamura, S., Ochiai, H., Sasaki, T., and Ohashi, Y. 2002. Enhanced resistance to seed transmitted bacterial diseases in transgenic rice plants overproducing an oat cell-wall-bound thionin. Mol. Plant-Microbe Interact. 15:515-521.

Jung, H. W., Kim, W., and Hwang, B. K. 2003. Three pathogen-inducible genes encoding lipid transfer protein from pepper are differentially activated by pathogens, abiotic, and environmental stresses. Plant Cell Environ. 26:915-928.

Jung, H. W., Kim, K. D., and Hwang, B. K. 2005. Identification of pathogen-responsive regions in the promoter of pepper lipid transfer protein gene $(C A L T P 1)$ and the enhanced resistance of the $C A L T P 1$ transgenic Arabidopsis against pathogen and environmental stresses. Planta 221:361-373

Kader, J. C. 1975. Proteins and the intracellular exchange lipids: Stimulation of phospholipids exchange between mitochondria and microssomal fractions by proteins isolated from potato tuber. Biochim. Biophys. Acta 380:31-44.

Kader, J. C. 1997. Lipid-transfer protein in plants Annu. Rev. Plant Physiol. Plant Mol. Biol. 47:627-654.

Kusumawati, L., Imin, N., and Djordjevic, M. A. 2008. Characterization of the secretome of suspension cultures of Medicago species reveals proteins important for defense and development. J. Proteome Res. 7:45084520

Lascombe, M. B., Bakan, B., Buhot, N., Marion, D., Blein, J. P., Larue, V., Lamb, C., and Prange, T. 2008. The structure of "Defective in Induced Resistance" protein of Arabidopsis thaliana, DIR1, reveals a new type of lipid transfer protein. Protein Sci. 17:1522-1530.

Lee, J. Y., Hoon Cha, K. M., Shin, D. H., Hwang, K. Y., and Suh, S. W. 1998. Rice non-specific lipid transfer protein: The 1.6 å crystal structure in the unliganded state reveals a small hydrophobic cavity. J. Mol. Biol. 276:437-448.

Lerche, M. H., Kragelund, B. B., Bech, L. M., and Poulsen, F. M. 1997. Barley lipid-transfer protein complexed with palmitoyl CoA: The structure reveals a hydrophobic binding site that can expand to fit both large and small lipid-like ligands. Structure 5:291-306.

Limpens, E., Ramos, J., Franken, C., Raz, V., Compaan, B., Franssen, H., Bisseling, T., and Geurts, R. 2004. RNA interference in Agrobacterium rhizogenes-transformed roots of Arabidopsis and Medicago truncatula. J. Exp. Bot. 55:983-992.

Maldonado, A. M., Dixon, P. A., Lamb, C. J., and Cameron, R. K. 2002. A putative lipid transfer protein involved in systemic resistance signalling in Arabidopsis. Nature 419:399-403.

Meade, H. M., Long, S. R., Ruvkun, G. B., Brown, S. E., and Ausubel, F. M. 1982. Physical and genetic characterization of symbiotic and auxotrophic mutants of Rhizobium meliloti induced by transposon Tn5 mutagenesis. J. Bacteriol. 149:114-122.

Mergaert, P., Nikovics, K., Kelemen, Z., Maunoury, N., Vaubert, D., 
Kondorosi, A., and Kondorosi, E. 2003. A novel family in Medicago truncatula consisting of more than 300 nodule-specific genes coding for small, secreted polypeptides with conserved cysteine motifs. Plant Physiol. 132:161-173.

Mithöfer, A. 2002. Suppression of plant defence in rhizobia-legume symbiosis. Trends Plant Sci. 7:440-444.

Mitra, R. M., and Long, S. R. 2004. Plant and bacterial symbiotic mutants define three transcriptionally distinct stages in the development of the Medicago truncatula/Sinorhizobium meliloti symbiosis. Plant Physiol. 134:595-604.

Molina, A., Segura, A., and García-Olmedo, F. 1993. Lipid transfer proteins (nsLTPs) from barley and maize leaves are potent inhibitors of bacterial and fungal plant pathogens. FEBS (Fed. Eur. Biochem. Soc.) Lett. 316:119-122.

Mourgues, F., Brisset, M. N., and Chevreau, E. 1998. Strategies to improve plant resistance to bacterial diseases through genetic engineering. Trends Biotechnol. 16:203-210.

Munnik, T. 2001. Phosphatidic acid: An emerging plant lipid second messenger. Trends Plant Sci. 6:227-233.

Nieuwland, J., Feron, R., Huisman, B. A. H., Fasolino, A., Hilbers, C. W. Derksen, J., and Mariani, C. 2005. Lipid transfer proteins enhance cell wall extension in tobacco. Plant Cell 17:2009-2019.

Pandolfini, T., Molesini, B., Avesani, L., Spena, A., and Polverari, A. 2003. Expression of self-complementary hairpin RNA under the control of the rolC promoter confers systemic disease resistance to plum pox virus without preventing local infection. BMC Biotechnol. 3:7.

Patkar, R. N., and Chattoo, B. B. 2006. Transgenic indica rice expressing ns-LTP-like protein shows enhanced resistance to both fungal and bacterial pathogens. Mol. Breed. 17:159-171.

Pii, Y., Crimi, M., Cremonese, G., Spena, A., and Pandolfini, T. 2007. Auxin and nitric oxide control indeterminate nodule formation. BMC Plant Biol. 7:21.

Pons, J. L., de Lamotte, F., Gautier, M. F., and Delsuc, M. A. 2003. Refined solution structure of a liganded type 2 wheat nonspecific lipid transfer protein. J. Biol. Chem. 278:14249-14256.

Quandt, H. J., Pühler, A., and Broer, I. 1993. Transgenic root nodules of Vicia hirsuta: A fast and efficient system for the study of gene expression in indeterminate-type nodules. Mol. Plant-Microbe Interact. 6:699706.

Regente, M. C., Giudici, A. M., Villalaín, J., and de la Canal, L. 2005. The cytotoxic properties of a plant lipid transfer protein involve membrane permeabilization of target cells. Lett. Appl. Microbiol. 40:183-189.

Roy-Barman, S., Sautter, C., and Chattoo, B. B. 2006. Expression of the lipid transfer protein Ace-AMP1 in transgenic wheat enhances antifungal activity and defense responses. Transgenic Res. 15:435-446.

Samuel, D., Liu, Y. J., Cheng, C. S., and Lyu, P. C. 2002. Solution struc- ture of plant nonspecific lipid transfer protein-2 from rice (Oryza sativa). J. Biol. Chem. 277:35267-35273.

Santos, R., Herouart, D., Sigaud, S., Touati, D., and Puppo, A. 2001. Oxidative burst in alfalfa-Sinorhizobium meliloti symbiotic interaction. Mol. Plant-Microbe Interact.14:86-89.

Scheidle, H., Groß, A., and Niehaus, K. 2005. The lipid A substructure of the Sinorhizobium meliloti lipopolysaccharides is sufficient to suppress the oxidative burst in host plants. New Phytol. 165:559-566.

Segura, A., Moreno, M., and Garcia Olmedo, F. 1993. Purification and antipathogenic activity of lipid transfer proteins (LTPs) from the leaves of Arabidopsis and spinach. FEBS (Fed. Eur. Biochem. Soc.) Lett. 332:243-246.

Tellstrom, V., Usadel, B., Thimm, O., Stitt, M., Kuster, H., and Niehaus, K. 2007. The lipopolysaccharide of Sinorhizobium meliloti suppresses defense-associated gene expression in cell cultures of the host plant Medicago truncatula. Plant Physiol. 143:825-837.

Terras, F. R. G., Goderis, I. J., Van Leuven, F., Vanderleyden, J., Cammue, B. P., and Broekaert, W. F. 1992. In vitro antifungal activity of a radish (Raphanus sativus L.) seed protein homologous to nonspecific lipid transfer proteins. Plant Physiol. 100:1055-1058.

Thompson, J. D., Higgins, D. G., and Gibson, T. J. 1994. CLUSTAL W: Improving the sensitivity of progressive multiple sequence alignment through sequence weighting, position-specific gap penalties and weight matrix choice. Nucleic Acids Res. 22:4673-4680.

van Brussel, A. A., Tak, T., Boot, K. J., and Kijne, J. W. 2002. Autoregulation of root nodule formation: Signals of both symbiotic partners studied in a split-root system of Vicia sativa subsp. nigra. Mol. PlantMicrobe Interact.15:341-349.

van Engelen, F. A., Molthoff, J. W., Conner, A. J., Nap, J. P., Pereira, A., and Stiekema, W. J. 1995. pBINPLUS: An improved plant transformation vector based on pBIN19. Transgenic Res. 4:288-290.

Van Loon, L. C., and Van Strien, E. A. 1999. The families of pathogenesisrelated proteins, their activities, and comparative analysis of PR-1 type proteins. Physiol. Mol. Plant Pathol. 55:85-97.

Wasternack, C., and Parthier, B. 1997. Jasmonate-signalled plant gene expression. Trends Plant Sci. 2:302-307.

Yang, X., Wang, X., Li, X., Zhang, B., Xiao, Y., Li, D., Xie, C., and Pei, Y. 2008. Characterization and expression of an nsLTPs-like antimicrobial protein gene from motherwort (Leonurus japonicus) Plant Cell Rep. 27:759-766.

Yeats, T. H., and Rose, J. K. C. 2008. The biochemistry and biology of extracellular plant lipid-transfer proteins (LTPs). Protein Sci. 17:191-198.

Zaccardelli, M., Balmas, V., Altomare, C., Corazza, L., and Scotti, C. 2006. Characterization of Italian isolates of Fusarium semitectum from alfalfa (Medicago sativa L.) by AFLP analysis, morphology, pathogenicity and toxin production. J. Phytopathol. 154:454-460. 